\title{
Groundwater vulnerability assessment to pollution in Kasihan, Bantul Regency: A comparative method study (GOD, SINTACS and DRASTIC)
}

\author{
Ignasius Loyola Setyawan Purnama ${ }^{1 *}$ and Vincentia Anindha Primacintya ${ }^{2}$ \\ ${ }^{1}$ Faculty of Geography, Universitas Gadjah Mada, Yogyakarta, Indonesia \\ ${ }^{2}$ Accounting Programme, Master of Science and Doctoral, Faculty of Economics and Business, Universitas Gadjah \\ Mada, Indonesia
}

\begin{abstract}
Groundwater vulnerability to pollution refers to the ease with which pollutants reach groundwater, in other words indicating the level of ease of an area to experience pollution. At present, the theme is one of the themes that attracts many researchers because pollution is more frequent in an area. The purpose of this study is to assess groundwater vulnerability in the study area for pollution using the GOD method and conduct a study of 3 groundwater vulnerability assessments, to determine the most appropriate assessment to be applied in the study area. The method used to determine groundwater vulnerability to pollution is GOD, which uses three parameters to assess the vulnerability of groundwater, namely aquifer type, rock type above aquifer and groundwater level. Furthermore, the results of the vulnerability assessment using the GOD method are compared with the vulnerability assessment according to the SINTACS and DRASTIC methods that have been carried out before in this area. The results showed that the variation of groundwater vulnerability index values in the study area according to the GOD method was from 0.35 to 0.63 . Locations that are classified as medium vulnerability are generally located in the limestone Sentolo Formation, while locations that are classified as high vulnerability class are located in the volcanic rock of Yogyakarta Formation. Noting the results of determining groundwater vulnerability from the three methods, it can be said that the three methods are suitable for assessing groundwater vulnerability in the study area. However, looking at the distribution pattern of the level of pollution, the DRASTIC method can provide more detailed results related to the level of vulnerability.
\end{abstract}

\section{Introduction}

Until now, groundwater is still the main source of water for humans to meet their needs for good quality water. As a result, the exploitation of these resources has intensified along with population growth and the advancement of civilization. To anticipate problems related to the existence of these resources, conservation efforts are needed.

Basically groundwater conservation efforts can be carried out through three activities namely protection of water catchment areas and increasing water absorption, monitoring groundwater extraction so as not to exceed limits, and controlling groundwater pollution. Efforts to protect water catchment areas and increase water absorption can be done by determining land use, land use mechanism according to the ability and suitability of the land as well as the creation of urban forests, determination of green lanes and determination of buffer zones. Efforts to conserve groundwater through monitoring groundwater extraction can be done by tightening the licensing process of making boreholes, installing water meters to record the amount of groundwater usage from boreholes, taxing groundwater use, there is an obligation for each borehole wells to make rainwater infiltration wells as deep as bore wells he made, restrictions on the use of groundwater only for domestic purposes and restrictions on the use of groundwater that does not exceed safe results.

In addition to the quantity aspect, groundwater conservation efforts must also pay attention to quality aspects, one of which can be done through pollution control. According to Al-Kuisi et al. [1], prevention of pollution is one aspect of groundwater management. The initial step in this effort is to map areas that are vulnerable to pollution.

At present, the theme related to groundwater vulnerability to pollution is one of the themes that attracts many researchers. This is not only indicated by the many themes of scientific articles published in journals, but also is indicated by several assessment methods compiled by several researchers. According to Civita [2], methods for assessing groundwater vulnerability to pollution that exist today are generally based on aspects of regional conditions, availability of data and the purpose of their use. This means that to get

\footnotetext{
* Corresponding author: Setyapurna@geo.ugm.ac.id
} 
reliable results, the selection of assessment methods to be applied in an area needs to pay attention to these three aspects.

According to Zhang et al. [3] and Magiera [4], in fact from some of the vulnerability assessment methods, can be grouped into three main types, namely the assessment method based on indexes and overlays, the statistical vulnerability assessment method and the vulnerability assessment based on the process. Of the three assessment methods, the index based assessment method is the most popular assessment method. This is not only caused by not too much data needed, the index method is also easier to apply [5]. The GOD, SINTACS and DRASTIC methods are some examples of groundwater vulnerability assessment methods intrinsically based on the index.

Besides Banguntapan and Sewon, Kasihan District is also one of the districts in Bantul Regency located in the periurban area of Yogyakarta City. Because of its location, this district experienced a rapid development, shown by the increasing population and the development of settlements. The impact is that more and more domestic waste is produced which can contaminate groundwater, so that potentially groundwater in anytime this is possible has a high vulnerability to pollution. The purpose of this study is to assess groundwater vulnerability in the study area for pollution using the GOD method and to study three groundwater vulnerability assessments (GOD, SINTACS and DRASTIC), to determine the most appropriate assessment to be applied in the study area.

\section{Method of research}

\subsection{GOD groundwater vulnerability asesment}

In addition to secondary data in the form of rock type data obtained from bricks and Geological Maps, this study also requires primary data in the form of phreatic level, for this purpose a measurement of the phreatic level of the observation surface will be carried out. Determination of observation wells was done by purposive sampling by considering the location of measurements that had been made by Purnama [6].

In this study, the method used to determine groundwater vulnerability to pollution is GOD which uses three parameters to assess the vulnerability of free groundwater. The parameter is abbreviated as GOD with $\mathrm{G}$ is Groundwater occurrence which is defined as the type of aquifer, $\mathrm{O}$ is Overall lithology which is defined as the type of rock above the aquifer and D is Depth to groundwater table which is defined as the depth of groundwater level [7]. GOD was developed by Foster in 1987 and revised again in 1998 [8]. The rating values of each of these parameters are shown in Tables 1, 2 and 3.

Table 1. Rating of aquifer type (Foster, 1998)

\begin{tabular}{|l|c|}
\hline Aquifer Type & Rating \\
\hline Unconfined aquifer & 1.0 \\
\hline Semi unconfined aquifer & 0.5 \\
\hline Semi confined aquifer & 0.3 \\
\hline Confined aquifer & 0.2 \\
\hline
\end{tabular}

\begin{tabular}{|l|c|}
\hline Aquifer Type & Rating \\
\hline Artesian aquifer (over flowing) & 0.1 \\
\hline Non aquifer & 0.0 \\
\hline
\end{tabular}

Table 2. Rating of rock type (Foster, 1998)

\begin{tabular}{|l|c|}
\hline \multicolumn{1}{|c|}{ Rock Type Above The Aquifer } & Rating \\
\hline Fractured or karstic limestone & 1.0 \\
\hline Limestone & 0.9 \\
\hline Gravel & 0.8 \\
\hline Sand and gravel; sandstone; tufa & 0.7 \\
\hline $\begin{array}{l}\text { Aeolian sand; siltite; tufa; igneous } \\
\text { rock }\end{array}$ & 0.6 \\
\hline $\begin{array}{l}\text { Limon alluvial; loess; shale, fine } \\
\text { limestone }\end{array}$ & 0.5 \\
\hline Residual Soil & 0.4 \\
\hline
\end{tabular}

Table 3. Rating of phreatic depth (Foster, 1998)

\begin{tabular}{|c|c|}
\hline Phreatic Depth (m) & Rating \\
\hline$<2$ & 1.0 \\
\hline $2-5$ & 0.9 \\
\hline $5-10$ & 0.8 \\
\hline $10-20$ & 0.7 \\
\hline $20-50$ & 0.6 \\
\hline $50-100$ & 0.5 \\
\hline$>100$ & 0.4 \\
\hline
\end{tabular}

To get the groundwater vulnerability index value is done by multiplying the rating of each GOD parameter. The value of the multiplication results shows the vulnerability category as shown in Table 4 .

Tabel 4. Vulnerability index of GOD (Foster, 1998)

\begin{tabular}{|l|c|}
\hline \multicolumn{1}{|c|}{ Vulnerability Index } & Value \\
\hline No vulnerability & $0.00-0.05$ \\
\hline Low vulnerability & $0.06-0.25$ \\
\hline Medium vulnerability & $0.26-0.55$ \\
\hline High vulnerability & $0.55-0.75$ \\
\hline Very high vulnerability & $0.75-1.00$ \\
\hline
\end{tabular}

\subsection{Comparison of assesment methods}

To examine three groundwater vulnerability assessment methods in Kasihan District, the results of the study with the GOD method were compared with the SINTACS and DRASTIC vulnerability assessments that were carried out previously in this district by Purnama in 2019 [6] and Wijaya and Purnama in 2018 [9].

\section{Result and discussion}

\subsection{Location and area of study}

Astronomically, Kasihan District is located at $114^{\circ} 22^{\prime} 24^{\prime \prime}-114^{\circ} 24^{\prime} 45^{\prime \prime} \quad$ East and $7^{\circ} 42^{\prime} 20^{\prime \prime}$ $7^{\circ} 45^{\prime} 24^{\prime \prime}$ South. Administratively it is divided into four village namely Bangunjiwo with an area of $15.43 \mathrm{~km}^{2}$, Tirtonirmolo with an area of $5.13 \mathrm{~km}^{2}$, Tamantirto with an area of $6.72 \mathrm{~km}^{2}$ and Ngestiharjo with an area of 5.10 $\mathrm{km}^{2}$, so that the total area of Kasihan District is 32.38 $\mathrm{km}^{2}$. Judging from the condition of its population, when 
has this density of 2900 people $/ \mathrm{km}^{2}$ with a population growth rate of $2.53 \%$.

\subsection{Geology, soil and hydrology}

Judging from the properties of the rock, there are two rock formations in the District of Kasihan, namely the Yogyakarta Formation which is volcanic rock and the Sentolo Formation which is limestone. The existence of two rock formations, causing the presence of two types of soil, namely regosol and grumusol.

Hydrologically, the eastern and northern parts of Kasihan District are included in the Merapi Aquifer System, which is a multiplayer aquifer. This aquifer system has relatively similar hydraulic properties and are interconnected with one another. Groundwater in this aquifer system flows from north to south with increasingly smaller hydraulic gradients, with aquifer transmissivity values ranging from $894 \mathrm{~m}^{2} \mathrm{~d}^{-1}$ to $1400 \mathrm{~m}^{2} \mathrm{~d}^{-1}$ and specific yields of $22 \%$ to $28.8 \%$. In Kasihan District, the thickness of the Merapi Aquifer System is increasingly thinning due to the presence of the limestone outcrop, which is the base of the Yogyakarta Formation.

\subsection{Climate and rainfall}

Like the rest of Java, the climate in Kasihan District is affected by monsoon. During the months of October to April when the sun is located in the southern hemisphere, Australia's mainland is a low pressure center so that the wind blows from mainland Asia which is a center of high pressure. When through the equator this wind is diverted from the northeast to the northwest. When passing through the island of Java, the wet monsoon winds become the west wind so it is often called the wet west monsoon wind. During this period Java experienced a rainy season. Conversely, from May to October, mainland Asia became the center of low pressure and Australia became the center of high pressure. A monsoon blows from Australia and does not carry water vapor, so parts of Java experience a dry season.

Based on this explanation, it can be said that the climatic conditions in Kasihan District include the Wet Tropika climate which is influenced by changes in wind direction. In the dry season the wind moves from the southeast, while in the rainy season the wind moves from the northwest. In terms of rainfall, Kasihan District has an average annual rainfall of $2,223 \mathrm{~mm}$, with the most rainfall and rainy days occurring in January. The temperature of the Kasihan District is in the range of $26^{\circ} \mathrm{C}$ to $28{ }^{\circ} \mathrm{C}$. with relative humidity ranging from $73 \%$ to $89 \%$.

Judging from the length of solar radiation, the length of solar radiation in the Kasihan District is around $56 \%$ to $72 \%$ per day with the amount of solar radiation varying between $17.47 \mathrm{Wm}-2$ in June and $20.48 \mathrm{Wm}-2$ in October.

Based on observations from 1998-2006, according to Oldeman Kasihan District, the climate is D. This means that this region generally has relatively small rainfall, with 5-6 consecutive wet months and 2-4 dry months.

Groundwater vulnerability to pollution refers to the ease with which pollutants reach groundwater. This concept shows the level of ease of an area to experience pollution. Determination of groundwater vulnerability is often done through index calculations and map depictions, which can then be used to identify areas threatened with pollution. As stated in the GOD method, it uses three parameters to assess groundwater vulnerability, namely aquifer type, rock type above the aquifer and groundwater depth. Because the study area is entirely free aquifers, all of them have a rating value of 1 .

The rock type above the aquifer is a hydrogeological system that can function as a barrier of pollutants if the rock texture is impermeable. Therefore, shale is given a low rating because it is impervious to be able to withstand contaminants, while gravel is given a high rating because of its porous nature. Field observations show that the study area is composed of sand and fine limestone material. The Yogyakarta Formation is composed by sand, while the Sentolo Formation is compesed of fine limestone. In rating the GOD Method the sand material was given a value of 0.7 , while the fine limestone material was given a value of 0.5 .

Because the study area is entirely in the form of a free aquifer, what is meant by groundwater depth is the phreatic level of land surface. The groundwater depth aspect has an important influence on susceptibility to pollution because it determines the time of absorption of waste and chemical processes during its absorption. The rating of GOD related to groundwater depth is that the smaller the rating the deeper the phreatic level. The results of measurements in the field show that the groundwater phreatic level in the study area ranges from $4.53 \mathrm{~m}$ to $12.47 \mathrm{~m}$, so the rating is 0.7 to 0.9 .

Furthermore, based on the rating of each parameter groundwater vulnerability index can be calculated for each measurement and observation location (Table 5). The results of calculations at 9 measurement and observation locations show variations in groundwater vulnerability index values from 0.35 to 0.63 . Judging from the level of vulnerability, 5 locations are classified as medium vulnerability and 4 locations are classified as high vulnerability. Based on this data, a Groundwater Vulnerability to Pollution Map can be made in the study area (Figure 1).

\subsection{Calculation of groundwater vulnerability}

Table 5. Calculation of GOD Vulnerability Index

\begin{tabular}{|c|c|c|c|c|c|c|c|c|}
\hline \multirow{2}{*}{$\begin{array}{c}\text { Number } \\
\text { of Well }\end{array}$} & \multicolumn{2}{|c|}{ Type of Aquifer } & \multicolumn{2}{|c|}{ Type of Rock } & \multicolumn{2}{c|}{ Depth of Phreatic (m) } & \multicolumn{2}{c|}{ Vulnerability Index } \\
\cline { 2 - 9 } & Type & Rating & Type & Rating & Depth & Rating & Value & Class \\
\hline 1 & Unconfined & 1 & Sand & 0.7 & 8.29 & 0.8 & 0.56 & High \\
\hline 2 & Unconfined & 1 & Sand & 0.7 & 7.08 & 0.8 & 0.56 & High \\
\hline
\end{tabular}




\begin{tabular}{|c|l|l|l|l|c|c|c|c|}
\hline \multirow{2}{*}{$\begin{array}{c}\text { Number } \\
\text { of Well }\end{array}$} & \multicolumn{2}{|c|}{ Type of Aquifer } & \multicolumn{2}{c|}{ Type of Rock } & \multicolumn{2}{c|}{ Depth of Phreatic $(\mathrm{m})$} & \multicolumn{2}{c|}{ Vulnerability Index } \\
\cline { 2 - 9 } & Type & Rating & \multicolumn{1}{|c|}{ Type } & Rating & Depth & Rating & Value & Class \\
\hline 3 & Unconfined & 1 & Fine limestone & 0.5 & 4.53 & 0.9 & 0.45 & Medium \\
\hline 4 & Unconfined & 1 & Sand & 0.7 & 10.10 & 0.7 & 0.49 & Medium \\
\hline 5 & Unconfined & 1 & Sand & 0.7 & 8.36 & 0.8 & 0.56 & High \\
\hline 6 & Unconfined & 1 & Fine limestone & 0.5 & 7.23 & 0.8 & 0.40 & Medium \\
\hline 7 & Unconfined & 1 & Fine limestone & 0.5 & 12.47 & 0.7 & 0.35 & Medium \\
\hline 8 & Unconfined & 1 & Sand & 0.7 & 4.97 & 0.9 & 0.63 & High \\
\hline 9 & Unconfined & 1 & Fine limestone & 0.5 & 4.64 & 0.9 & 0.45 & Medium \\
\hline
\end{tabular}

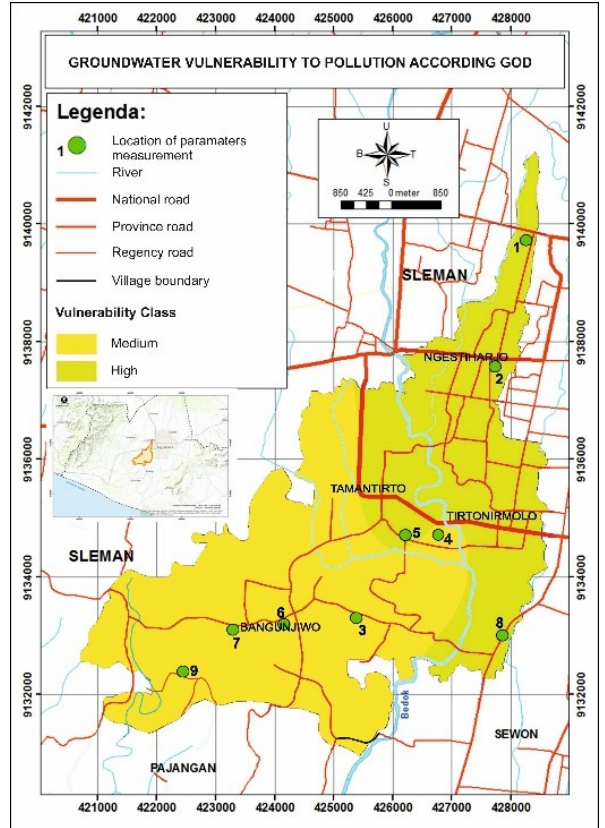

Fig. 1. Map of groundwater vulnerability to pollution according GOD method

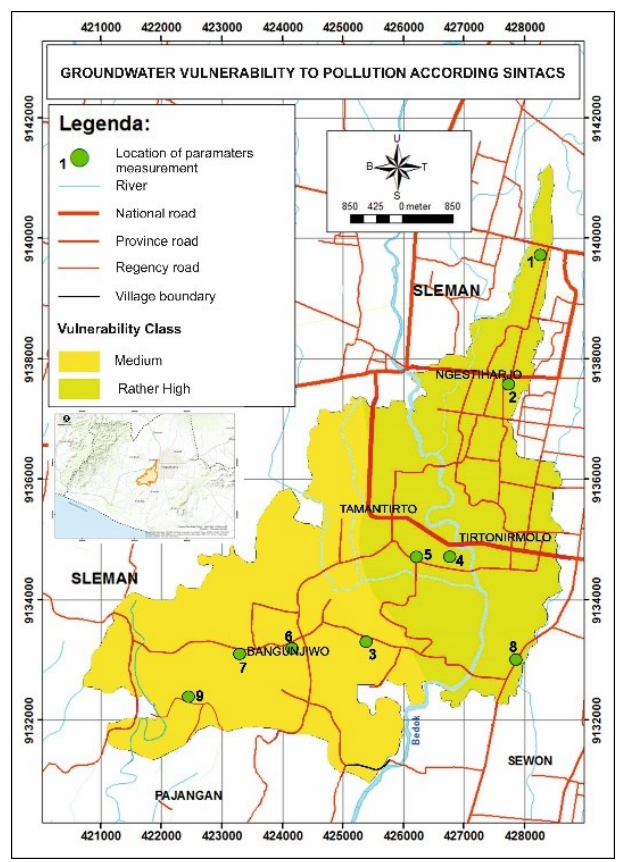

Fig. 2. Map of groundwater vulnerability to pollution according SINTACS method

In view of Figure 1, locations that are classified as medium vulnerability are generally located in the Sentolo Formation which is limestone and has a grumusol soil type, while the location classified as high vulnerability class is located in the Yogyakarta Formation which is volcanic rock and regosol soil type. This means that aspects of geology and soil type determine the level of groundwater vulnerability to pollution in the study area.

\subsection{Comparison analiysis of the methods}

Comparing the three groundwater vulnerability maps in the study area, it can be said that all three methods show similar patterns almost related to pollution areas (figure 2 and 3). In general, the volcanic Yogyakarta Formation has a higher level of pollution than the limestone Sentolo Formation. The difference is in naming the level of pollution. The volcanic rock Yogyakarta Formation has a high level of vulnerability according to GOD, rather high according to SINTACS and high according to DRASTIC, while the limestone Sentolo Formation has medium vulnerability according to GOD, medium according to SINTACS and very low-medium according to DRASTIC. Noting the results of determining groundwater vulnerability from the three methods, it can be said that the three methods are suitable for assessing groundwater vulnerability in the study area. However, looking at the distribution pattern of the level of pollution, the DRASTIC method can provide more detailed results related to the level of vulnerability

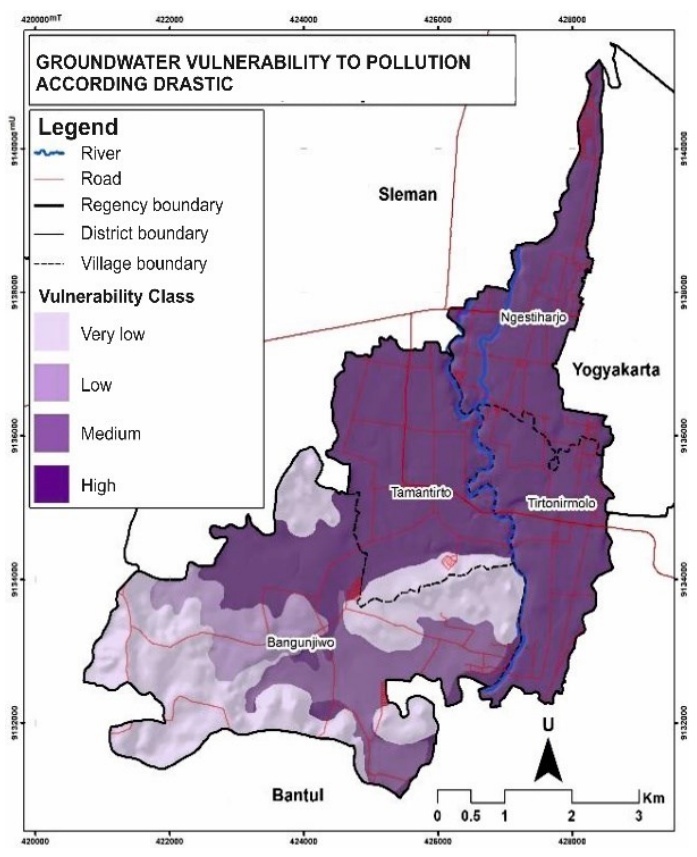

Fig. 3. Map of groundwater vulnerability to pollution according DRASTIC method 


\section{Conclusion}

According to the GOD method the study area has a variation of groundwater vulnerability index values from 0.35 to 0.63 , with 5 locations classified as medium vulnerability and 4 locations classified as high vulnerability.

Locations that are classified as medium vulnerability are generally located in the Sentolo Formation which is limestone rocky and has a grumusol soil type, while the location classified as high vulnerability class is located in the Yogyakarta Formation which is volcanic rocky and regosol soil type.

Paying attention to the results of determining groundwater vulnerability from the three methods, it can be said that the three methods are suitable for assessing groundwater vulnerability in the study area. However, looking at the distribution pattern of the level of pollution, the DRASTIC method can provide more detailed results related to the level of vulnerability.

This article is the result of a study of the same title funded by the Community Fund of the Faculty of Geography, Universitas Gadjah Mada Fiscal Year 2020.

\section{References}

1. M. Al-Kuisi, A. El-Naqa, N. Hammouri, Jordan. Environ Geol 50: 651-667 (2006).

2. M. Civita, Journal of Water Resources and Protection 2: 14-28 (2010).

3. R. Zhang, J.D. Hamerlinck, S.P. Glos, L. Munn, Journal of Environmental Quality 25: 411-418 (1996).

4. P. Magiera, Groundwater 5: 103-114 (2000).

5. J.E. Liggett, S. Talwar, Streamline Watershed Management Bulletin 13,1: 18-29 (2009).

6. S. Purnama, Indonesia. Forum Geografi, 33,2: (2019).

7. S.S.D. Foster, Aquifer Recharge and Vulnerability (Special Publications of Geological Society, London), 130: 7-22 (1998).

8. J.P.L. Ferreira, M.M. Oliveira. Geofísica Internacional, 43,4: 541-550 (2004).

9. K.A. Wijaya, S. Purnama, Jurnal Bumi Indonesia, 7,1: 1-10 (2018). 